\title{
PERANCANGAN OTOMATIS PERHITUNGAN EARNED VALUE PADA PROYEK PEMBANGUNAN DENGAN MENGGUNAKAN BAHASA PEMROGRAMAN C\#
}

\author{
Rudi Desmanto ${ }^{1}$ dan Hendrik Sulistio² \\ ${ }^{1}$ Program Studi Sarjana Teknik Sipil, Universitas Tarumanagara, Jl. Letjen S. Parman No.1 Jakarta \\ rudi.325170131@stu.untar.ac.id \\ ${ }^{2}$ Program Studi Sarjana Teknik Sipil, Universitas Tarumanagara, J1. Letjen S. Parman No.1 Jakarta \\ Hendriks@ft.untar.ac.id
}

Masuk: 10-01-2021, revisi: 02-03-2021, diterima untuk diterbitkan: 24-03-2021

\begin{abstract}
Earned Value Analysis is one of the methods used in project control to integrate costs and time. Earned Value Analysis is calculated using the C\# programming language assistance tool to implement the Gudang Garam Nasional construction work. The method used is Earned Value Analysis. This study's results are equipped with a clear description of the steps that must be taken when starting programming in the C\# programming language. For the calculation results of Earned Value Analysis using the Earned Value Analysis program - Rudto 2020 on several Gudang Garam Nasional projects from week 1 to week 2. (1) North Aceh Gudang Garam Nasional has poor cost performance and good timing; (2) Indramayu Gudang Garam Nasional has poor performance and poor costs; (3) Demak Gudang Garam Nasional has poor cost and time performance; (4) Jepara Gudang Garam Nasional has good cost performance but poor time performance; (5) Pati Gudang Garam Nasional has poor cost performance but good time performance; (6) Pamekasan Gudang Garam Nasional has poor cost performance but good time performance.
\end{abstract}

Keywords: Earned value analysis; Gudang Garam Nasiona; C\#

\begin{abstract}
ABSTRAK
Earned Value Analysis merupakan salah satu metode yang digunakan dalam pengendalian proyek untuk mengintegrasikan biaya dan waktu. Earned Value Analysis dihitung dengan menggunakan alat bantuan bahasa pemrograman C\# pada pelaksanaan pekerjaan konstruksi Gudang Garam Nasional. Metode yang digunakan adalah Earned Value Analysis. Hasil Penelitian ini dilengkapi deskripsi secara jelas langkah-langkah yang harus dilakukan ketika memulai pembuatan program dengan bahasa pemrograman C\#. Untuk hasil perhitungan Earned Value Analysis dengan menggunakan program Earned Value Analysis - Rudto 2020 pada beberapa proyek Gudang Garam Nasional dari minggu ke-1 hingga minggu ke-2. (1) Gudang Garam Nasional Aceh Utara memiliki kinerja biaya yang buruk dan waktu yang baik; (2) Gudang Garam Nasional Indramayu memiliki kinerja yang buruk dan biaya yang buruk; (3) Gudang Garam Nasional Demak memiliki kinerja biaya dan waktu yang buruk; (4) Gudang Garam Nasional Jepara kinerja biaya yang baik namun kinerja waktu yang buruk; (5) Gudang Garam Nasional Pati memiliki kinerja biaya yang buruk namun kinerja waktu yang baik; (6) Gudang Garam Nasional Pamekasan memiliki kinerja biaya yang buruk namun kinerja waktu yang baik.
\end{abstract}

Kata kunci: Earned value analysis; Gudang Garam Nasional; C\#

\section{PENDAHULUAN}

Proyek pembangunan di Indonesia saat ini begitu pesat dalam proses pelaksanaan konstruksi sering terjadi keterlambatan yang dipengaruhi oleh beberapa masalah, seperti ketidaksesuaian antara pekerjaan dan material yang digunakan dengan atas petunjuk teknis dengan dokumen perencanaan sehingga mempengaruhi biaya yang akan dikeluarkan. Manajemen proyek adalah semua perencanaan, pelaksanaan, pengendalian dan koordinasi suatu proyek dari awal (gagasan) sampai selesainya proyek untuk menjamin bahwa proyek dilaksanakan tepat waktu, tepat biaya, dan tepat mutu. (Ervianto, 2005)

Menurut Iman Soeharto (1999) kegiatan proyek dapat diartikan sebagai satu kegiatan sementara yang berlangsung dalam jangka waktu terbatas, dengan alokasi sumber daya tertentu dan dimaksudkan untuk menghasilkan produk 
atau deliverable yang kriteria mutunya telah digariskan dengan jelas. Di dalam proses mencapai tujuan tersebut, ada batasan yang harus dipenuhi yaitu besar biaya (anggaran) yang dialokasikan, jadwal, serta mutu yang harus dipenuhi. Ketiga hal tersebut merupakan parameter penting bagi penyelenggara proyek yang sering diasosiasikan sebagai sasaran proyek. Ketiga batasan di atas disebut tiga kendala (triple constraint). Perhatikan Gambar 1 (Soeharto, 1999)

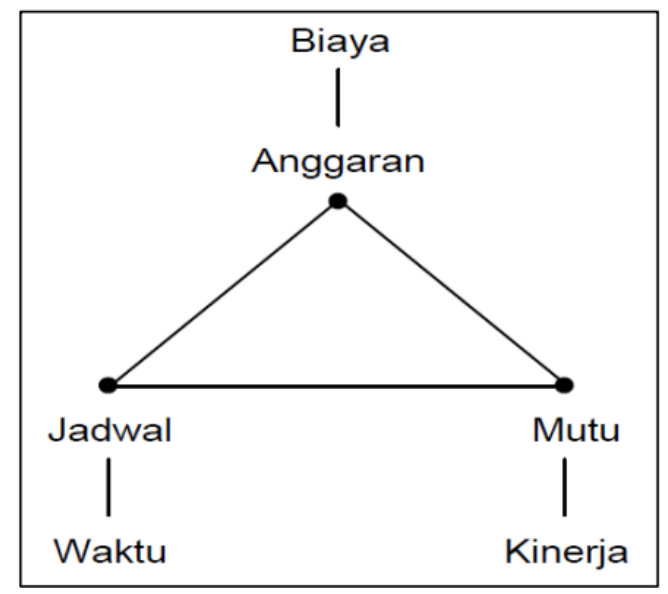

Gambar 1. Hubungan triple constraint (Soeharto, 1999)

a) Anggaran. Proyek harus diselesaikan dengan tidak boleh melebihi anggaran yang direncanakan. Untuk nilai proyek dalam jumlah yang besar dan jadwal pengerjaan yang sangat lama, anggarannya akan dijadikan per periode tertentu yang jumlahnya disesuaikan dengan keperluan.

b) Jadwal. Proyek harus dikerjakan sesuai dengan kurun waktu dan jadwal akhir yang telah ditentukan. Bila hasil akhir adalah produk baru, maka penyerahannya tidak boleh melewati batas waktu yang ditentukan.

c) Mutu. Hasil kegiatan proyek yang harus memenuhi spesifikasi dan kriteria yang dipersyaratkan. Apabila memenuhi persyaratan mutu berarti mampu memenuhi tugas yang dimaksudkan atau disebut sebagai fit for the intended use.

Ketiga batasan tersebut saling berhubungan. Misalkan, apabila ingin meningkatkan kinerja suatu produk yang telah disepakati dalam kontrak, maka umumnya harus diikuti dengan meningkatkan mutu. Hal ini selanjutnya berakibat pada naiknya biaya sehingga melebihi anggaran. Sebaliknya, bila ingin menekan suatu anggaran, maka biasanya akan mempengaruhi mutu atau jadwal. Pada umumnya keberhasilan proyek dikaitkan dengan sejauh mana ketiga sasaran tersebut dapat dipenuhi.

Salah satu proyek pembangunan di Indonesia yaitu konstruksi Gudang Garam Nasional ini memiliki beberapa masalah ketidaksesuaian antara pekerjaan dan material yang digunakan dengan atas petunjuk teknis dengan dokumen perencanaan yang akan mempengaruhi biaya dan waktu rencana. Oleh karena itu, diperlukan suatu metode "Earned Value Analysis" untuk memperhitungkan kinerja waktu dan biaya pelaksanaan pekerjaan sampai di tahap akhir proyek agar tidak mengalami kerugian atau keterlambatan. Perhitungan Earned Value Analysis dihitung dengan menggunakan alat bantuan bahasa pemrograman C\#.

Manfaat pada penelitian ini bagi perencanaan proyek untuk mengetahui informasi mengenai performa proyek dalam jangka waktu tertentu serta dapat memperkirakan pelaksanaan proyek pada priode selanjutnya. Sedangkan, bagi keilmuan untuk menambah kesan ilmu pengetahuan dalam bidang program software terapan mengenai manajemen konstruksi terutama earned value.

\section{Earned Value}

Earned Value merupakan salah satu metode pengendalian proyek yang digunakan untuk mengintegrasikan biaya dan waktu (Santoso, 2020). Penggunaan earned value dalam penilaian kinerja proyek dijelaskan pada Gambar 2. Beberapa istilah yang terkait dengan penilaian ini sebagai berikut. 


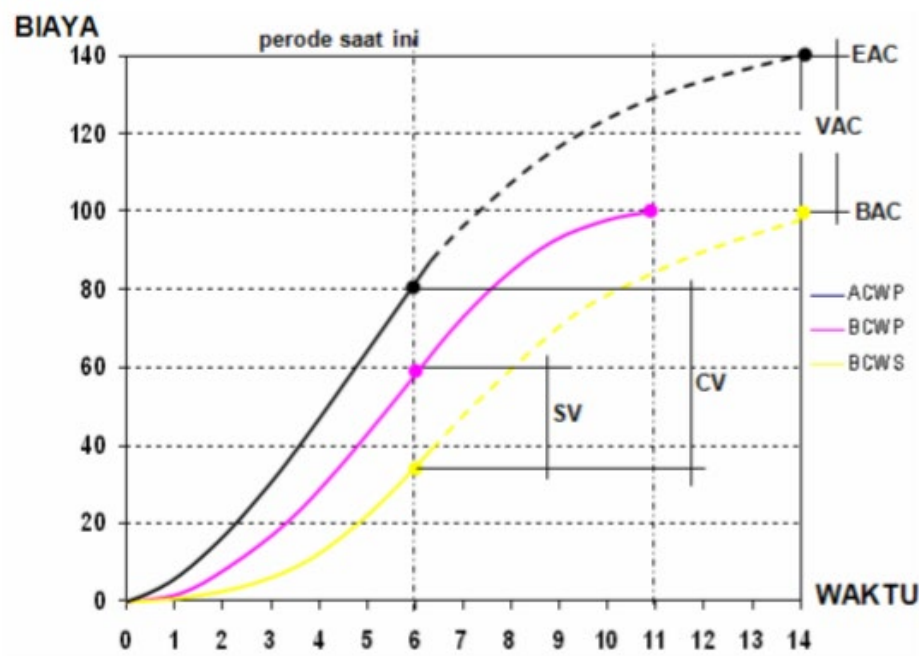

Gambar 2. Grafik kurva S earned value (Sumber: Soemardi et al., 2007)

1. Actual Cost for Work Performed (ACWP) merupakan nilai aktual dari pengeluaran atau dana yang digunakan untuk pelaksanaan pekerjaan pada kurun waktu tertentu. (Ervianto, 2004 dalam Rifqi Auzan N., 2017)

2. Budgeted Cost for Work Performed (BCWP) adalah nilai atau biaya yang akan dikeluarkan sesuai dengan progress yang terlaksanakan. (Ervianto, 2004 dalam Rifqi Auzan N., 2017)

$$
\text { BCWP }=\text { Nilai Kontrak x \%Aktual }
$$

3. Budgeted Cost for Work Scheduled (BCWS) adalah anggaran yang direncanakan untuk kegiatan yang harus dilaksanakan. (Ervianto, 2004 dalam Rifqi Auzan N., 2017)

$$
\text { BCWS = Nilai Kontrak x \%Rencana }
$$

4. Cost Variance (CV)

Cost variance merupakan selisih antara nilai yang diperoleh setelah menyelesaikan pekerjaan dengan biaya aktual yang terjadi selama pelaksanaan proyek.

$$
\mathrm{CV}=\mathrm{BCWP}-\mathrm{ACWP}
$$

5. Schedule variance (SV)

Schedule variance merupakan penyimpangan antara BCWS dengan BCWP.

$$
\mathrm{SV}=\mathrm{BCWP}-\mathrm{BCWS}
$$

6. Cost Performance Index (CPI)

Bobot nilai yang diperoleh terhadap perbandingan antara nilai pekerjaan yang secara fisik telah diselesaikan (BCWP) dengan biaya yang telah dikeluarkan dalam periode yang sama (ACWP).

$$
\mathrm{CPI}=\frac{\mathrm{BCWP}}{\mathrm{ACWP}}
$$


7. Schedule Performance Index (SPI)

Besaran pekerjaan yang mampu diselesaikan terhadap perbandingan antara nilai pekerjaan yang secara fisik telah diselesaikan (BCWP) dengan rencana pengeluaran biaya yang dikeluarkan berdasarkan rencana pekerjaan (BCWS).

$$
\mathrm{SPI}=\frac{\mathrm{BCWP}}{\mathrm{BCWS}}
$$

Tabel 1. SV, CV, SPI, dan CPI

\begin{tabular}{lcc}
\hline \multicolumn{1}{c}{ Nama } & Nilai & Keterangan \\
\hline Cost Variance $(\mathrm{CV})$ & + & Biaya kurang dari budget \\
Schedule Variance $(\mathrm{SV})$ & - & Biaya melebihi dari budget \\
Cost Performance Index (CPI) & + & Pekerjaan lebih cepat dari rencana \\
& - & Pekerjaan terlambat dari rencana \\
Schedule Performance Index (SPI) & $>1$ & Biaya kurang dari budget \\
& $<1$ & Biaya melebihi dari budget \\
& $>1$ & Pekerjaan lebih cepat dari rencana \\
\end{tabular}

8. Estimate at Completion (EAC)

Estimate at Completion (EAC) merupakan perkiraan biaya antara penjumlahan nilai aktual dan sisa biaya untuk menyelesaikan proyek yang sudah terjadi progress. Bila persentase pekerjaan dibawah 50\%, dapat menggunakan persamaan sebagai berikut (Pramudita Budi Santoso, 2020):

$$
\mathrm{EAC}=\mathrm{ACWP}+(\mathrm{BAC}-\mathrm{BCWP})
$$

Bila persentase pekerjaan diatas 50\% sisa biaya akan memperhitungkan efektifias penggunaan biaya (CPI), dapat dilihat persamaan beriku (Pramudita Budi Santoso, 2020)t:

$$
\mathrm{EAC}=\mathrm{ACWP}+\frac{(\mathrm{BAC}-\mathrm{BCWP})}{\mathrm{CPI}}
$$

\section{Estimate All Schedule (EAS)}

Estimate All Schedule (EAS) merupakan perkiraan akhir total waktu untuk menyelesaikan dari penjumlahan antara sisa waktu dan minggu evaluasi. Bila persentase pekerjaan dibawah $50 \%$, dapat menggunakan persamaan sebagai berikut (M. Faridhol Miftha, dkk, 2018):

$$
\text { EAS }=\text { Waktu Evaluasi }+ \text { Sisa Waktu }
$$

Bila persentase pekerjaan diatas 50\% sisa waktu akan memperhitungkan efektifias penggunaan waktu (SPI), dapat dilihat persamaan berikut:

$$
\text { EAS }=\text { Waktu Evaluasi }+\frac{\text { Sisa Waktu }}{\text { SPI }}
$$

\section{METODE PENELITIAN}

\section{Teknik pengumpulan data}

Dalam penelitian, teknik pengumpulan data merupakan faktor penting untuk keberhasilan penelitian. Untuk mempermudah analisis agar peneitian mendapatkan hasil yang baik, diperlukan teknik pengumpulan data. Adapun salah satu teknik penumpulan data pada penelitian ini ialah data sekunder. Data sekunder adalah data yang 
diperoleh peneliti dari sumber yang sudah ada. Teknik ini digunakan untuk memperoleh data-data yang berkaitan dengan pelaksanaan pekerjaan, antara lain: laporan mingguan, rekapitulasi perhitungan pekerjaan, time schedule, dan actual cost dari kontraktor pelaksana pekerja.

\section{Analisis data}

Analisis yang digunakan dalam penelitian ini menggunakan Earned Value Analysis. Earned Value Analysis digunakan untuk menghitung kinerja waktu dan biaya pelaksanaan pekerjaan konstruksi Gudang Garam Nasional. Earned Value Analysis merupakan suatu teknik analisis yang digunakan untuk mengendalikan biaya dan jadwal proyek secara terpadu. Teknik analisis tersebut memberikan informasi status kinerja proyek pada suatu periode pelaporan dan memberikan informasi prediksi biaya yang dibutuhkan untuk penyelesaian seluruh pekerjaan berdasarkan indikator kinerja saat pelaporan. Dalam penelitian ini digunakan program C\# sebagai alat bantuan untuk menganalisis Earned Value Analysis.

\section{Diagram alir penelitian}

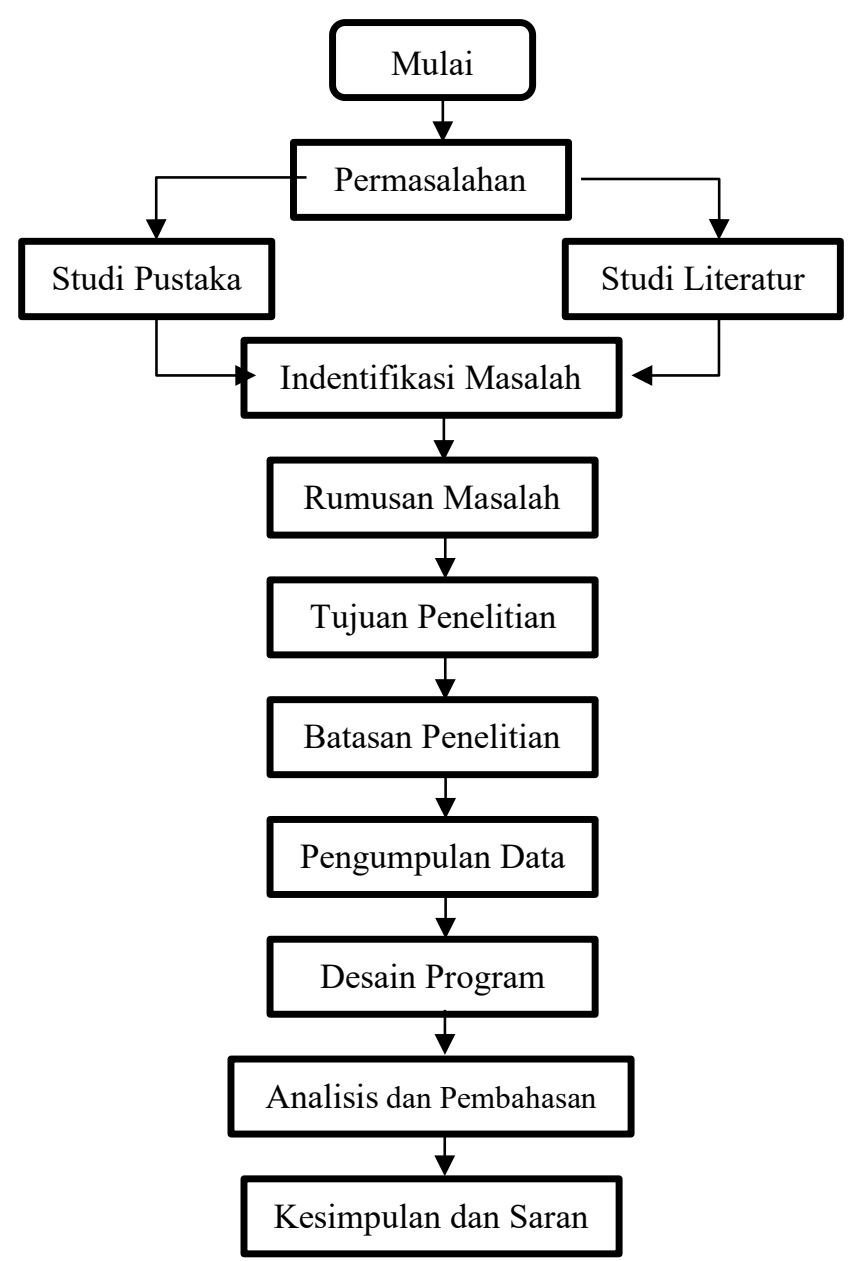

Gambar 3. Diagram alir penelitian 
Perancangan Otomatis Perhitungan Earned Value pada Proyek Pembangunan dengan Menggunakan Bahasa

Pemrograman C\#

\section{Flowchart analisis pada program}

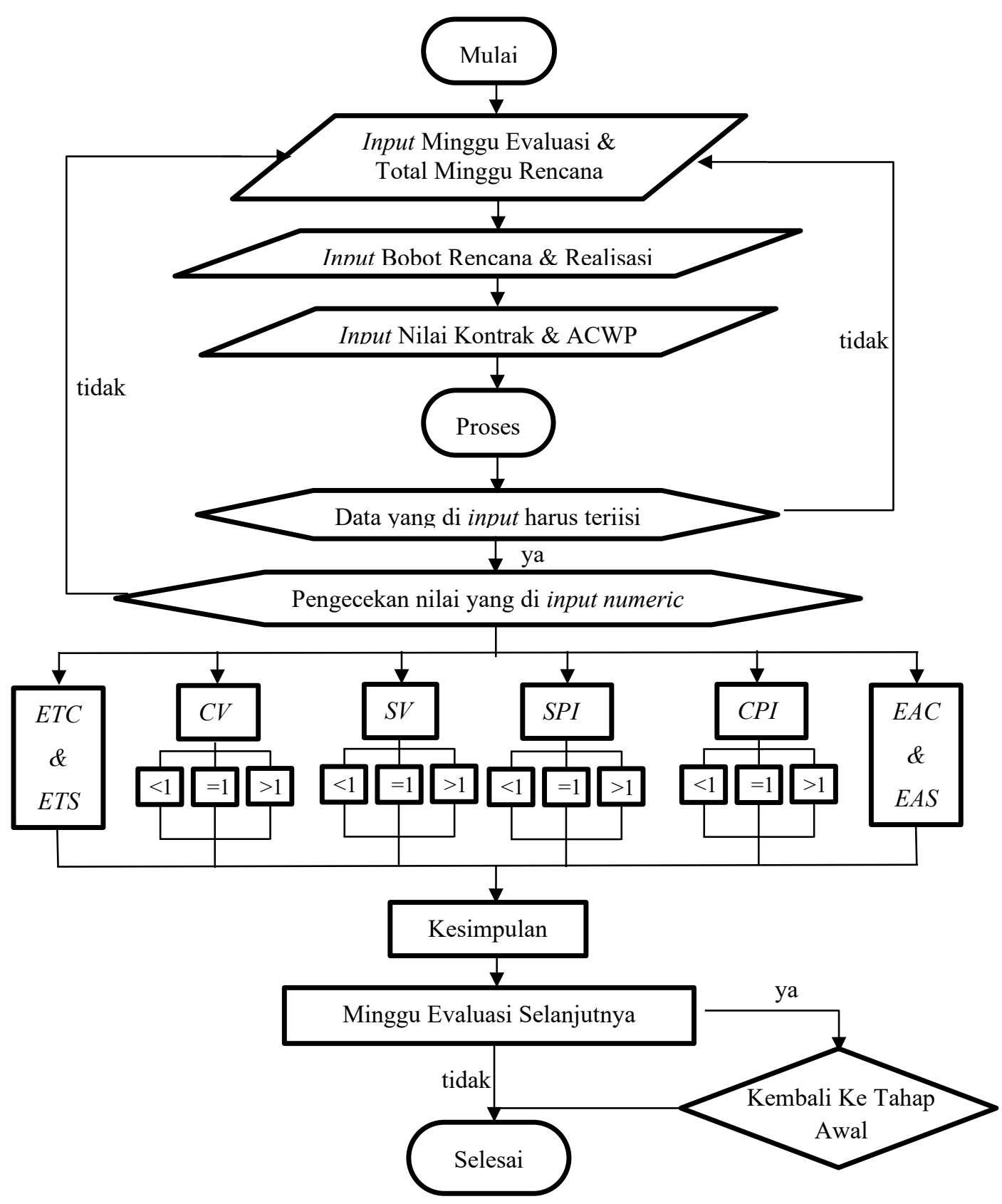

Gambar 4. Flowchart pada program

\section{HASIL DAN PEMBAHASAN}

\section{Desain program}

Desain program dilakukan dengan menggunakan bantuan aplikasi visual studio 2019 dengan bahasa pemrograman C\#. Berikut adalah langkah-langkah yang dilakukan pada saat melakukan desain pemrograman. 
- Buka aplikasi visual studio 2019 dan create a new project untuk membuka lembaran baru. Pada Gambar 5 merupakan cara untuk membuka lembaran baru pada aplikasi visual studio 2019.

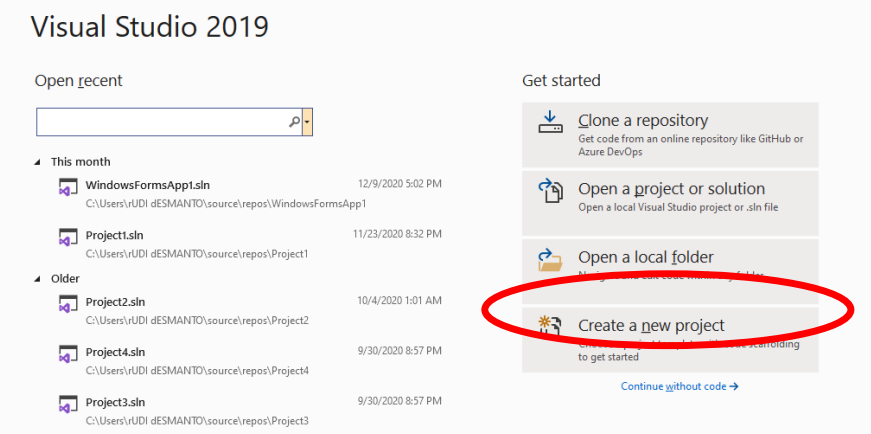

Gambar 5. create a new project

- Kemudian mengatur bahasa pemrograman C\# dan perangkat yang digunakan dan carilah "Windows Forms App (.NET Framework)" yang ditampilkan pada Gambar 6.

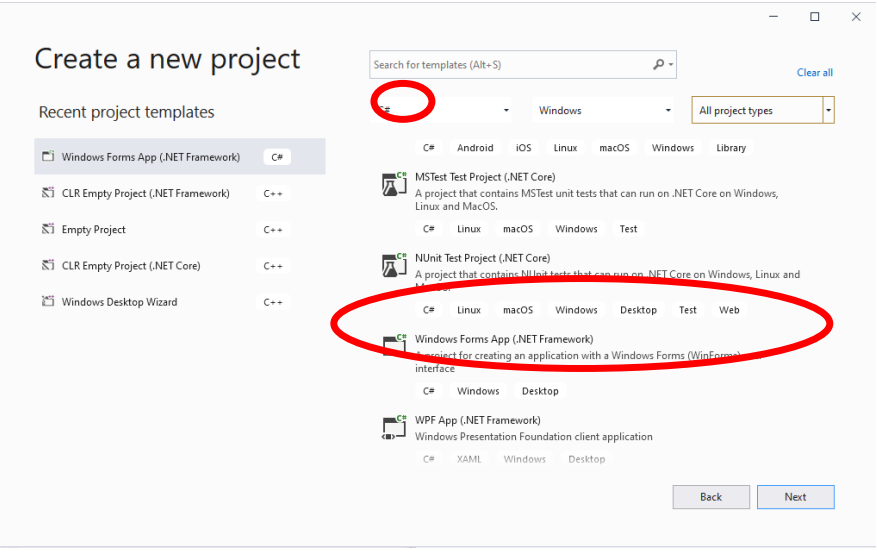

Gambar 6. Windows Forms App (.NET Framework)

- Mendesain form designer dengan menggunakan Toolbox. Pada Gambar 7 merupakan form designer untuk program Earned Value Analysis - Rudto 2020.

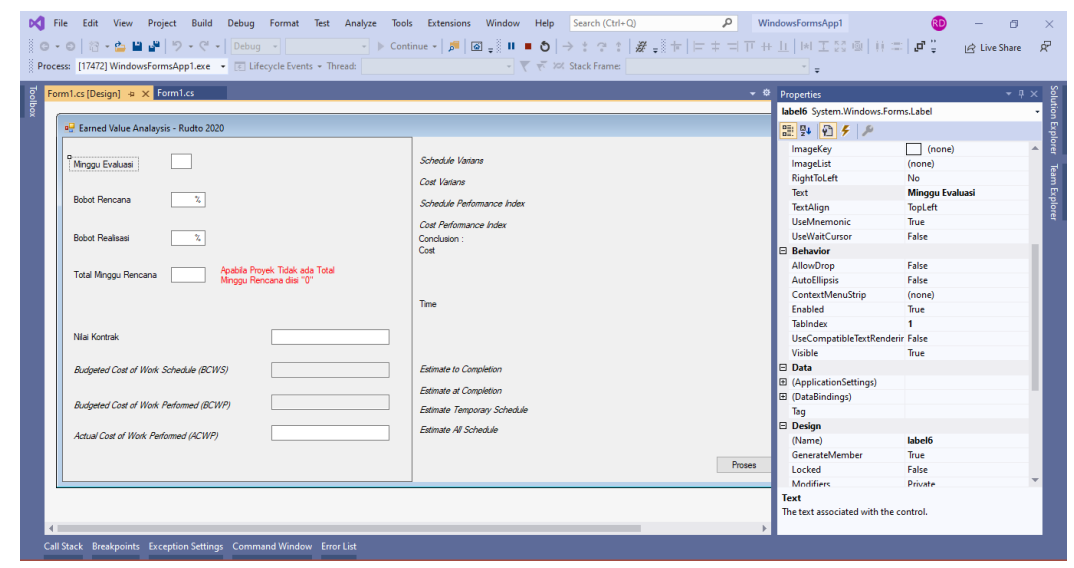

Gambar 7. Form designer 
Perancangan Otomatis Perhitungan Earned Value pada Proyek Pembangunan dengan Menggunakan Bahasa

Pemrograman C\#

- Mengcoding untuk perhitungan Earned Value Analysis pada lembar codingan yang dapat dilihat pada Gambar 8.

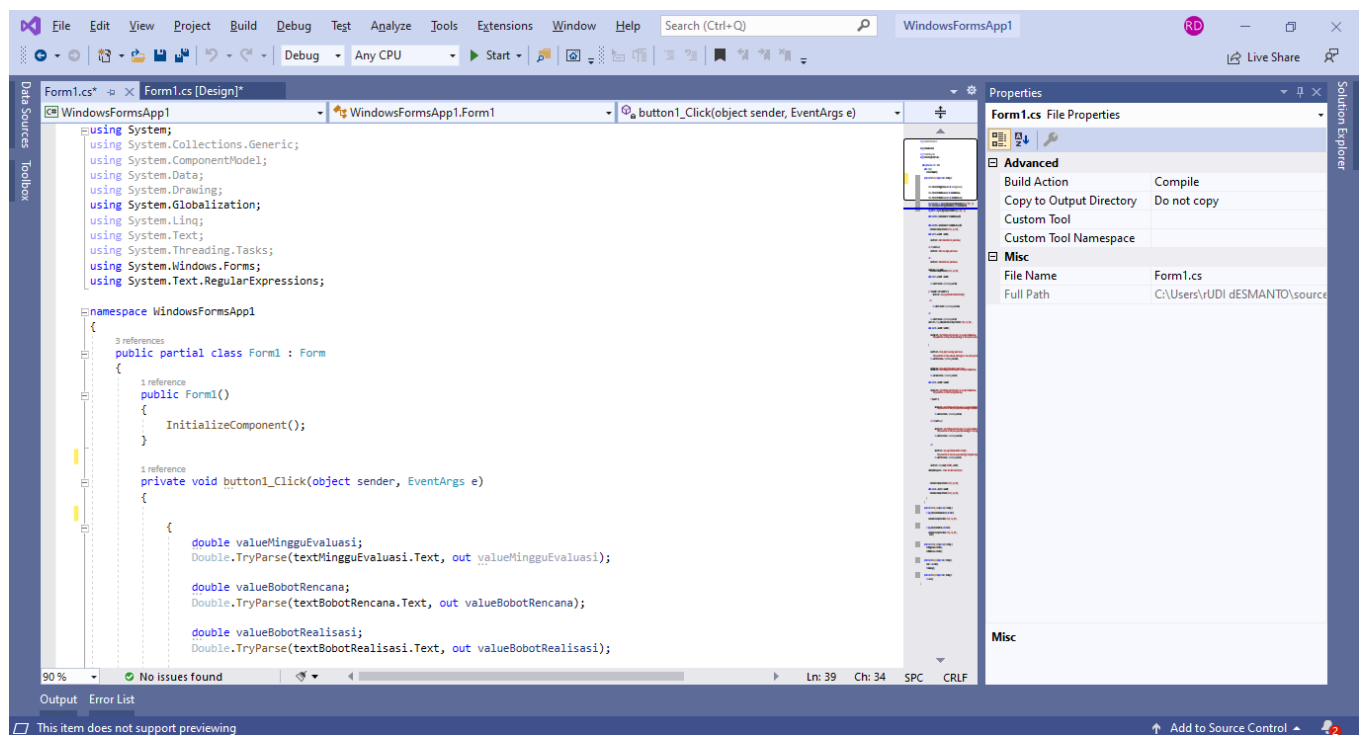

Gambar 8. Lembaran codingan

- Mengcopy form pertama ke form yang baru melalui solution explorer yang dapat dilihat pada Gambar 9.

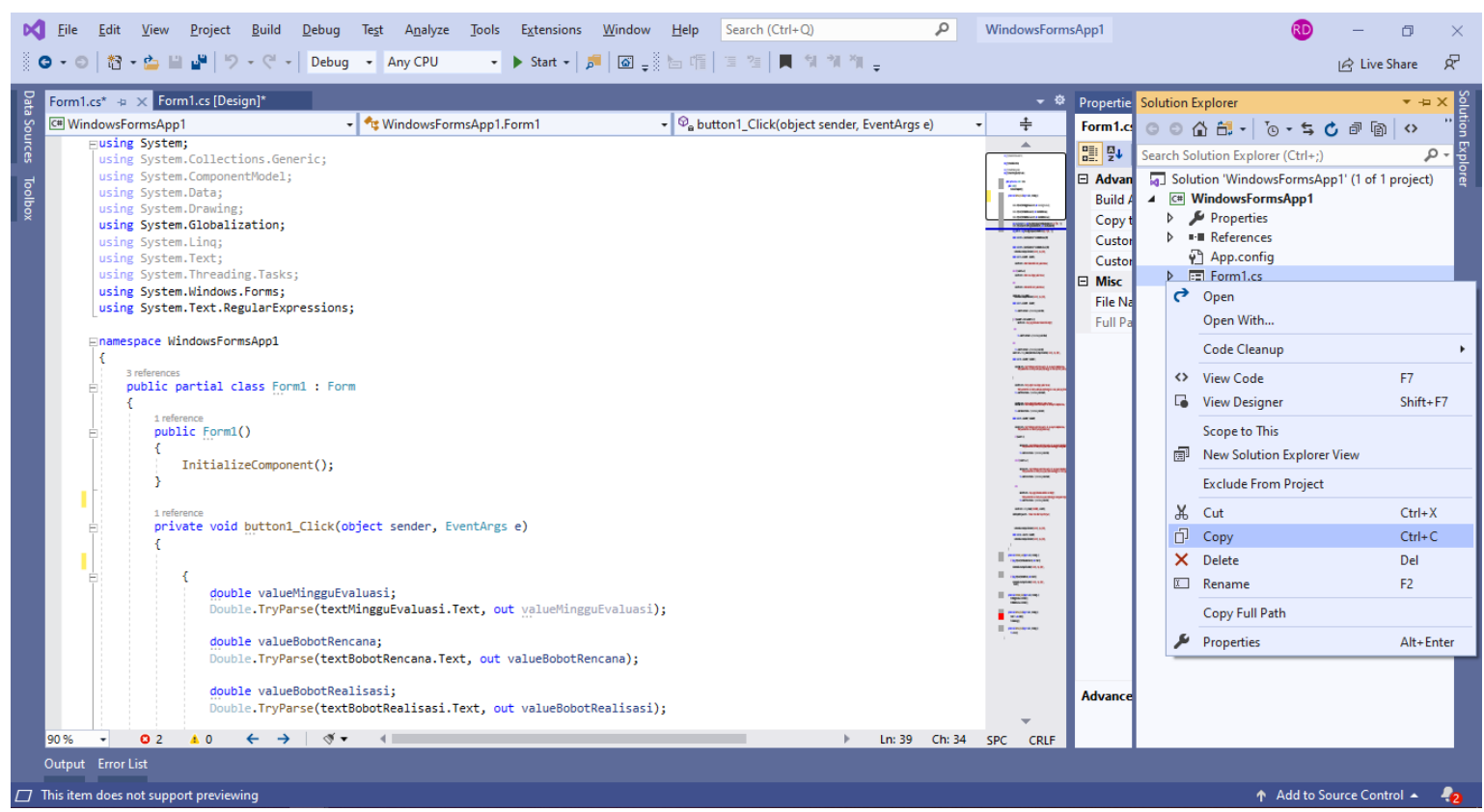

Gambar 9. Solution explorer 


\section{Perhitungan Earned Value Analysis menggunakan program C\# terhadap waktu dan biaya pada pekerjaan Gudang Garam Nasional}

Berikut Gambar 10 dan Gambar 11 yang merupakan perhitungan Earned Value Analysis pada pekerjaan Gudang Garam Nasional Aceh Utara menggunakan Bahasa Pemrograman C\#.

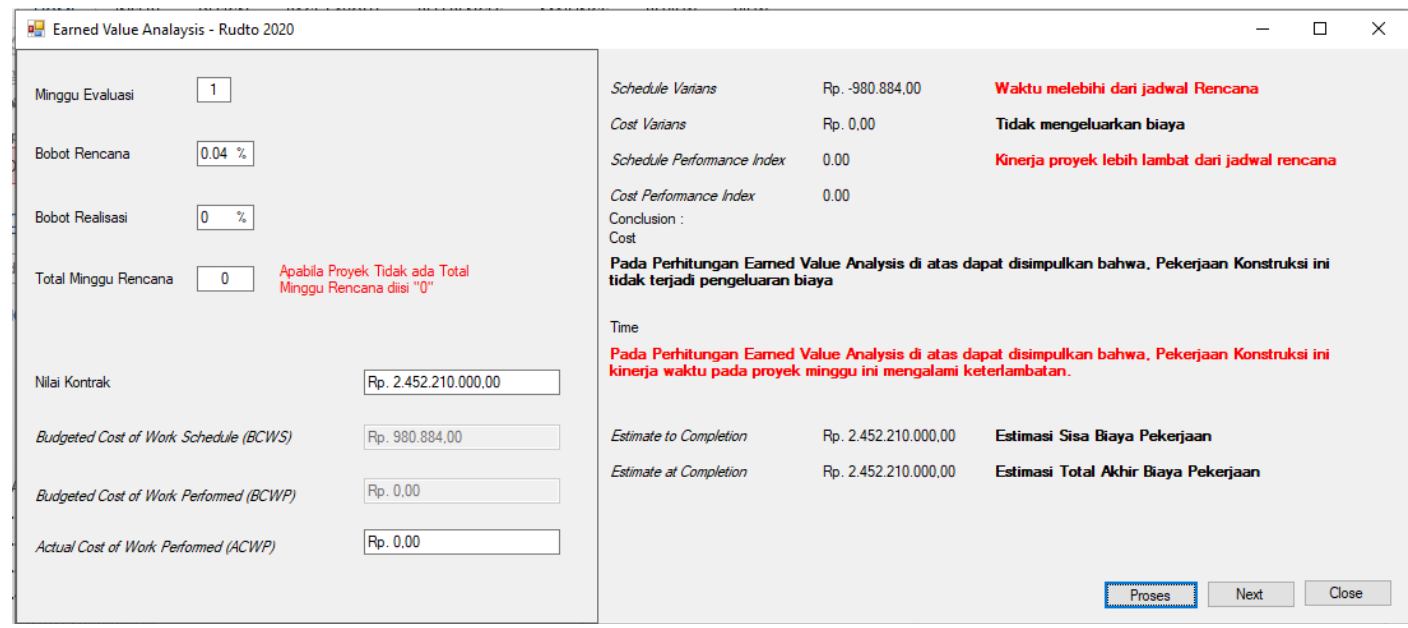

Gambar 10. Perhitungan EVA pekerjaan konstruksi Gudang Garam Nasional Aceh Utara minggu ke-1

Berdasarkan Gambar 10, perhitungan EVA yang dilakukan bedasarkan data proyek berupa nilai bobot rencana, nilai bobot realisasi, biaya aktual dan nilai kontrak proyek pada minggu ke-1 yang dapat disimpulkan bahwa:

- Waktu pelaksanaan pekerjaan konstruksi Gudang Garam Nasional Aceh Utara pada minggu ke-1 mengalami keterlambatan.

- Biaya pekerjaan Gudang Garam Nasional pada minggu ke-1 tidak terjadi pengeluaran biaya.

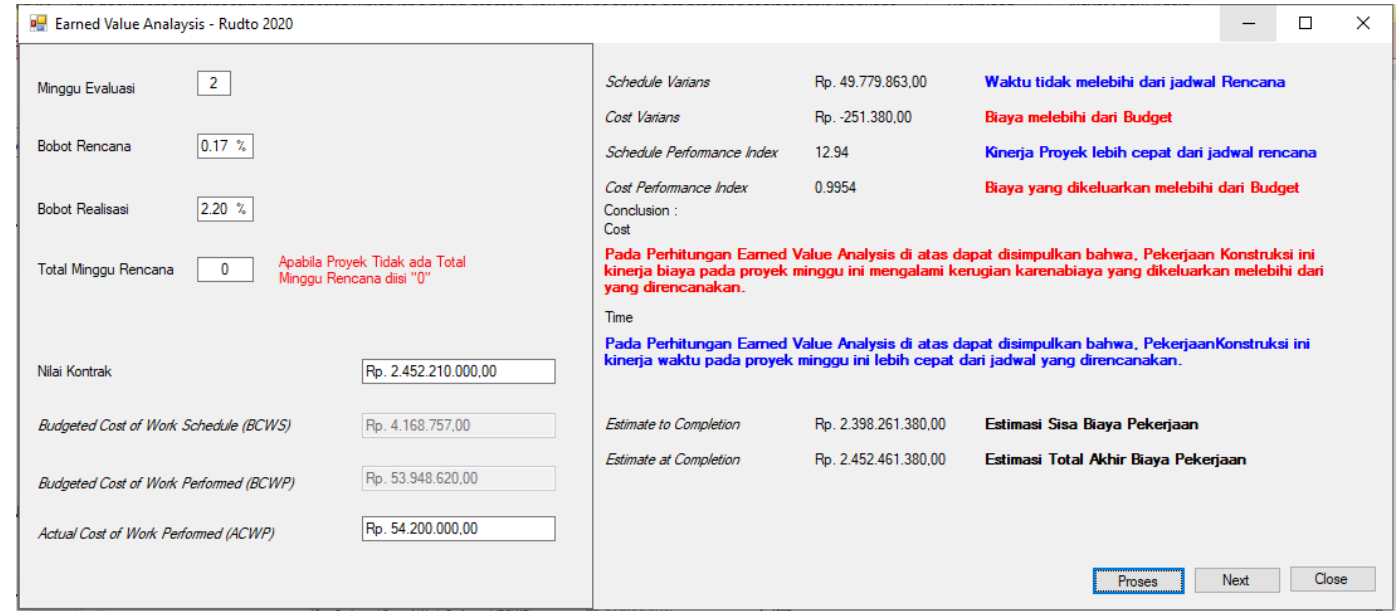

Gambar 11. Perhitungan EVA pekerjaan konstruksi Gudang Garam Nasional Aceh Utara minggu ke-2

Berdasarkan Gambar 11, perhitungan EVA yang dilakukan bedasarkan data proyek berupa nilai bobot rencana, nilai bobot realisasi, biaya aktual dan nilai kontrak proyek pada minggu ke-2 yang dapat disimpulkan bahwa:

- Waktu pelaksanaan pekerjaan konstruksi Gudang Garam Nasional Aceh Utara pada minggu ke-2 sesuai dengan jadwal.

- Biaya pekerjaan Gudang Garam Nasional pada minggu ke-2 mengalami kerugian sebesar Rp. 251.380,-. 
Perancangan Otomatis Perhitungan Earned Value pada

Rudi Desmanto, et al. Proyek Pembangunan dengan Menggunakan Bahasa Pemrograman C\#

Berikut Gambar 12 dan Gambar 13 yang merupakan perhitungan Earned Value Analysis pada pekerjaan Gudang Garam Nasional Indramayu menggunakan Bahasa Pemrograman C\#.

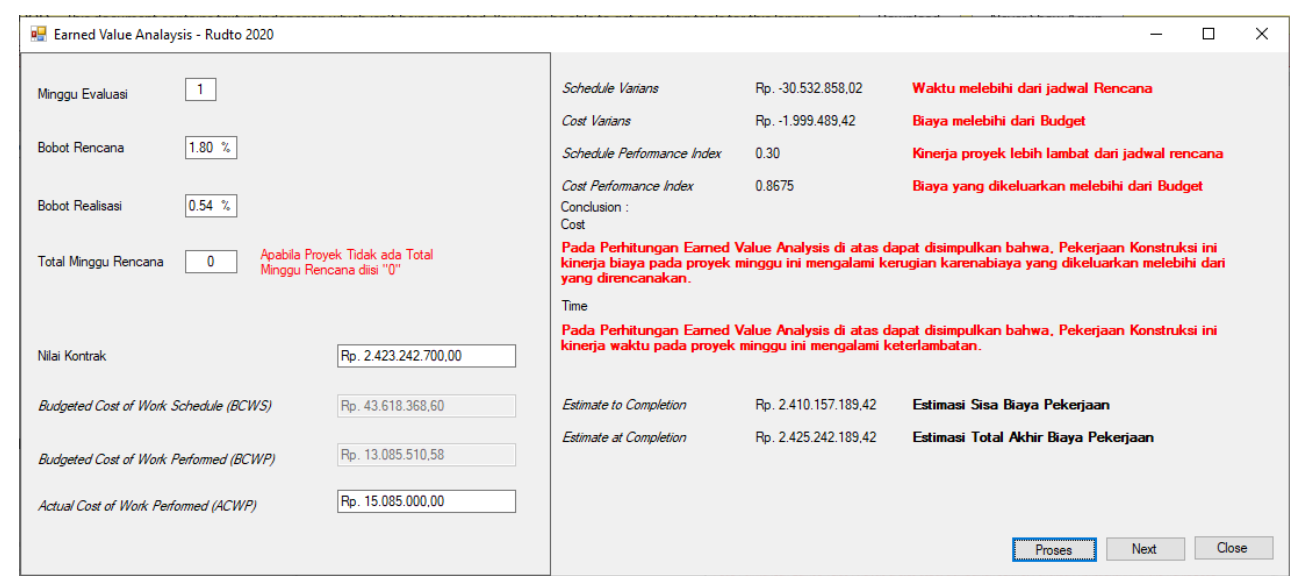

Gambar 12. Perhitungan EVA pekerjaan konstruksi Gudang Garam Nasional Indramayu minggu ke-1

Berdasarkan Gambar 12, perhitungan EVA yang dilakukan bedasarkan data proyek berupa nilai bobot rencana, nilai bobot realisasi, biaya aktual dan nilai kontrak proyek pada minggu ke-1 yang dapat disimpulkan bahwa:

- Waktu pelaksanaan pekerjaan konstruksi Gudang Garam Nasional Indramyu pada minggu ke-1 mengalami keterlambatan.

- Biaya pekerjaan Gudang Garam Nasional pada minggu ke-1 mengalami kerugian sebesar Rp. 1.999.489,-.

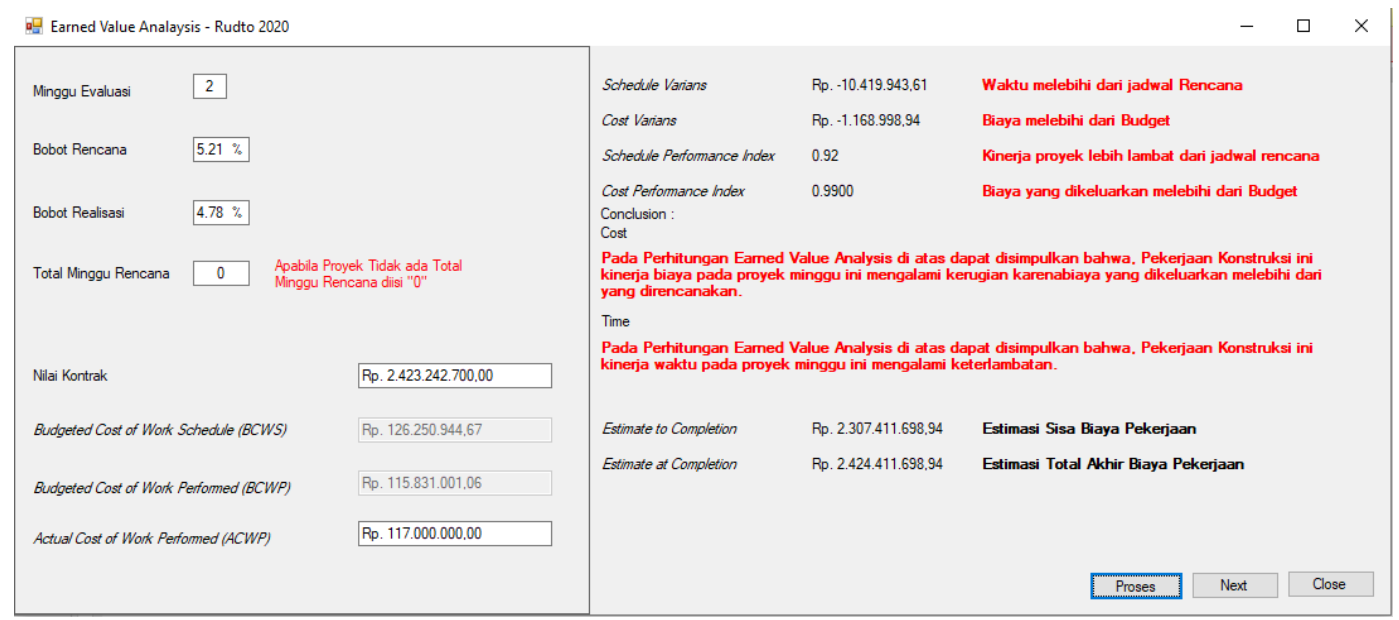

Gambar 13. Perhitungan EVA pekerjaan konstruksi Gudang Garam Nasional Indramayu minggu ke-2

Berdasarkan Gambar 13, perhitungan EVA yang dilakukan bedasarkan data proyek berupa nilai bobot rencana, nilai bobot realisasi, biaya aktual dan nilai kontrak proyek pada minggu ke-2 yang dapat disimpulkan bahwa:

- Waktu pelaksanaan pekerjaan konstruksi Gudang Garam Nasional Indramyu pada minggu ke-2 mengalami keterlambatan.

- Biaya pekerjaan Gudang Garam Nasional pada minggu ke-2 mengalami kerugian sebesar Rp. 1.168.999,-. 
Berikut Gambar 14 dan Gambar 15 yang merupakan perhitungan Earned Value Analysis pada pekerjaan Gudang Garam Nasional Demak menggunakan Bahasa Pemrograman C\#.

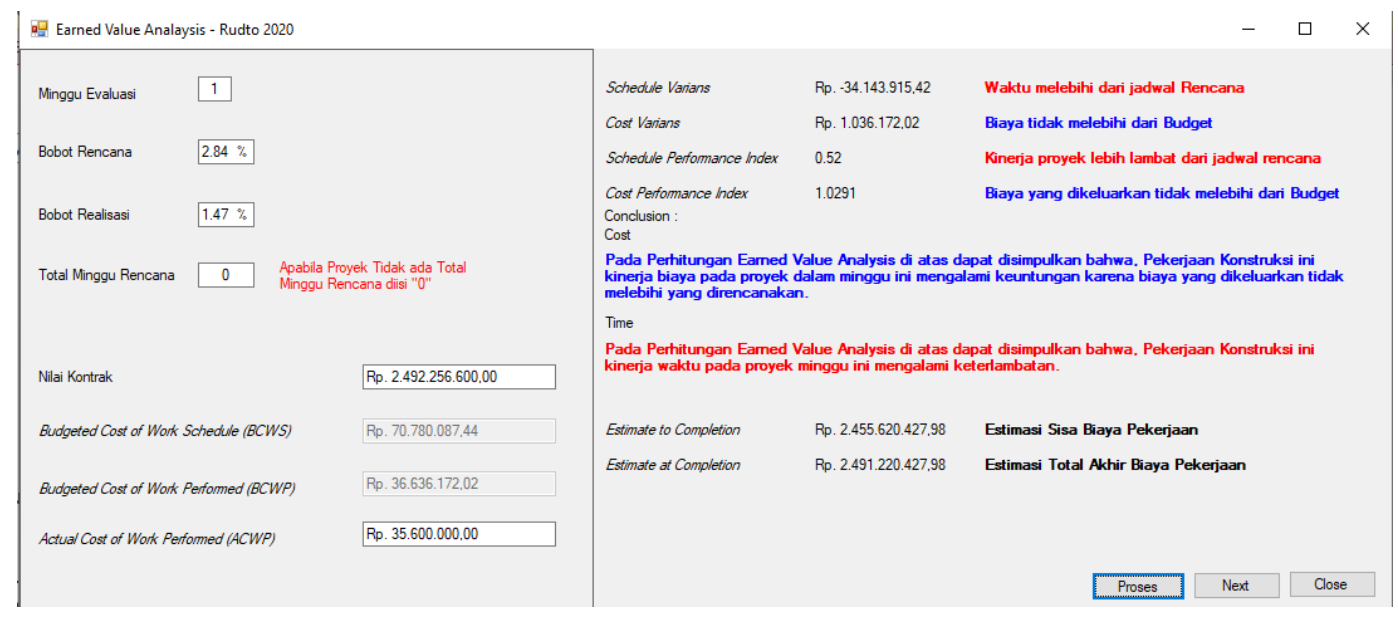

Gambar 14. Perhitungan EVA pekerjaan konstruksi Gudang Garam Nasional Demak minggu ke-1

Berdasarkan Gambar 14, perhitungan EVA yang dilakukan bedasarkan data proyek berupa nilai bobot rencana, nilai bobot realisasi, biaya aktual dan nilai kontrak proyek pada minggu ke-1 yang dapat disimpulkan bahwa:

- Waktu pelaksanaan pekerjaan konstruksi Gudang Garam Nasional Demak pada minggu ke-1 mengalami keterlambatan.

- Biaya pekerjaan Gudang Garam Nasional pada minggu ke-1 mengalami keuntungan sebesar Rp. 1.036.163,-

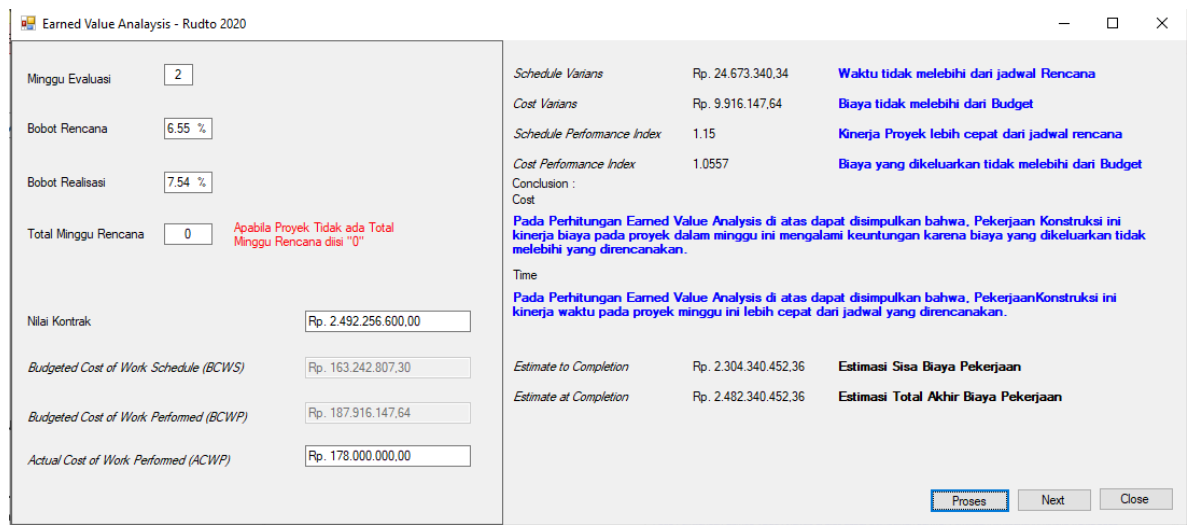

Gambar 15. Perhitungan EVA pekerjaan konstruksi Gudang Garam Nasional Demak minggu ke-2

Berdasarkan Gambar 15, perhitungan EVA yang dilakukan bedasarkan data proyek berupa nilai bobot rencana, nilai bobot realisasi, biaya aktual dan nilai kontrak proyek pada minggu ke-2 yang dapat disimpulkan bahwa:

- Waktu pelaksanaan pekerjaan konstruksi Gudang Garam Nasional Demak pada minggu ke-2 mengalami tepat waktu.

- Biaya pekerjaan Gudang Garam Nasional pada minggu ke-2 mengalami kerugian sebesar Rp. 9.916.102,-- 
Perancangan Otomatis Perhitungan Earned Value pada Rudi Desmanto, et al. Proyek Pembangunan dengan Menggunakan Bahasa Pemrograman C\#

Berikut Gambar 16 dan Gambar 17 yang merupakan perhitungan Earned Value Analysis pada pekerjaan Gudang Garam Nasional Jepara menggunakan Bahasa Pemrograman C\#.

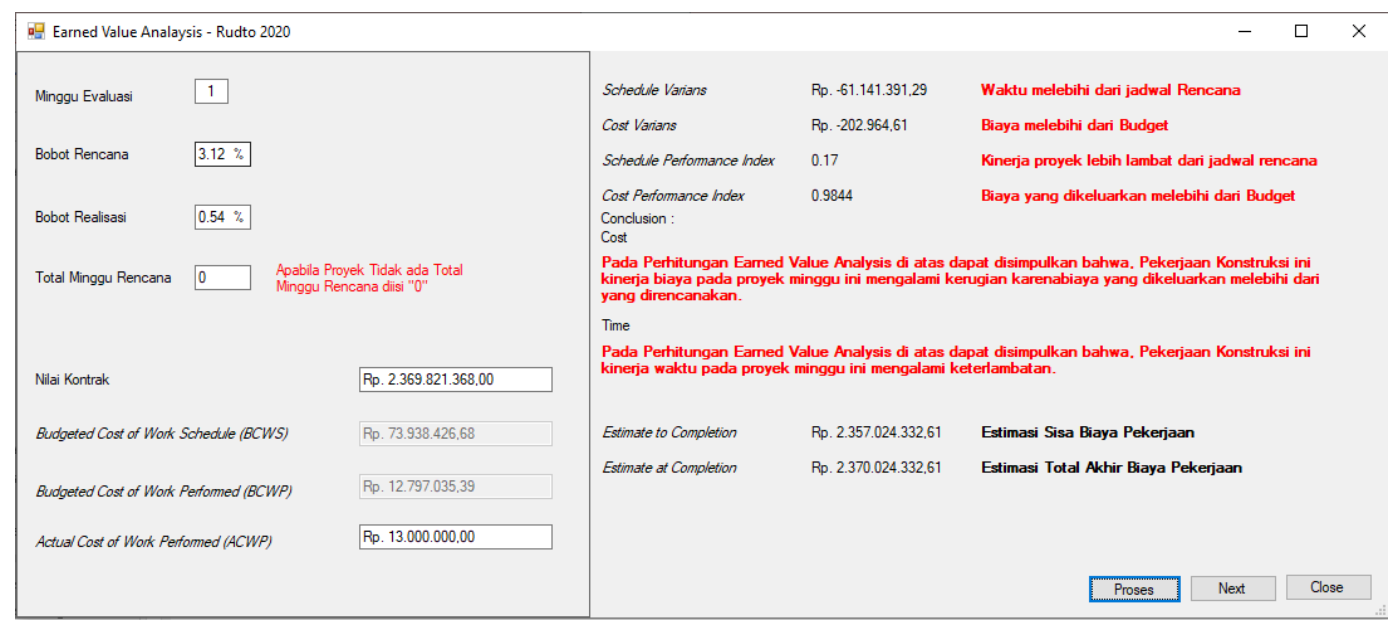

Gambar 16. Perhitungan EVA pekerjaan konstruksi Gudang Garam Nasional Jepara minggu ke-1

Berdasarkan Gambar 16, perhitungan EVA yang dilakukan bedasarkan data proyek berupa nilai bobot rencana, nilai bobot realisasi, biaya aktual dan nilai kontrak proyek pada minggu ke-1 yang dapat disimpulkan bahwa:

- Waktu pelaksanaan pekerjaan konstruksi Gudang Garam Nasional Jepara pada minggu ke-1 mengalami keterlambatan.

- Biaya pekerjaan Gudang Garam Nasional pada minggu ke-1 mengalami kerugian sebesar Rp. 202.965,--

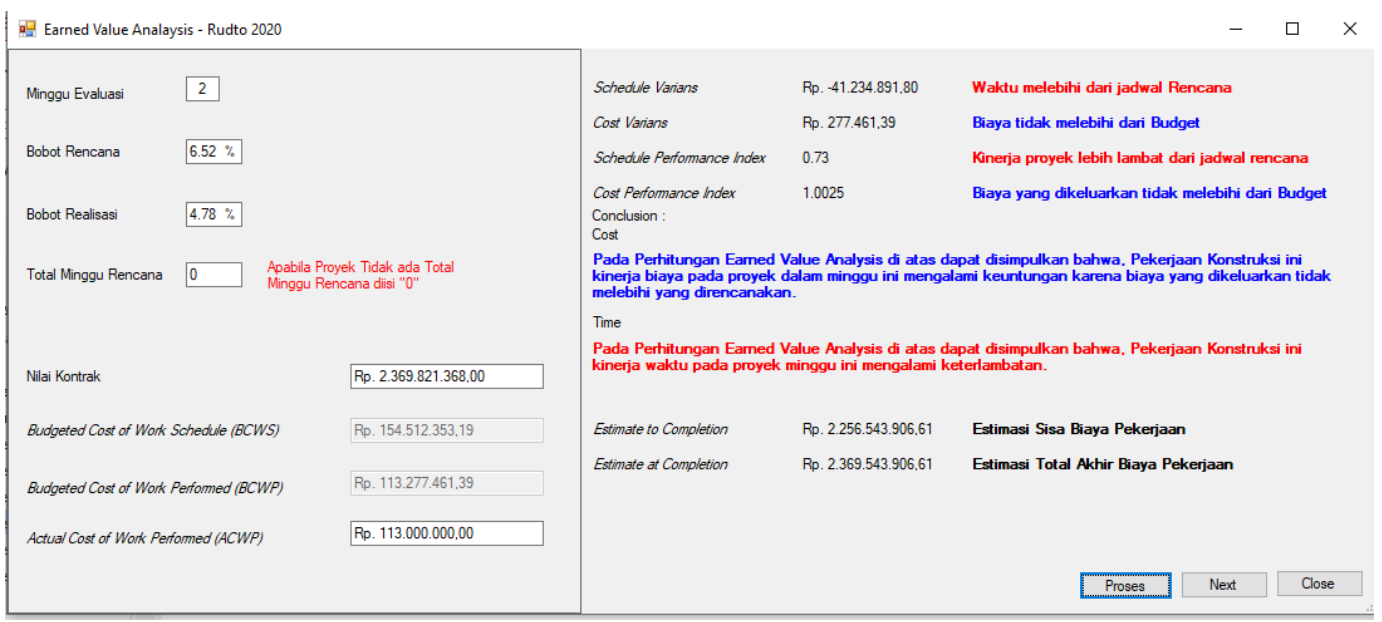

Gambar 17. Perhitungan EVA pekerjaan konstruksi Gudang Garam Nasional Jepara minggu ke-2

Berdasarkan Gambar 17, perhitungan EVA yang dilakukan bedasarkan data proyek berupa nilai bobot rencana, nilai bobot realisasi, biaya aktual dan nilai kontrak proyek pada minggu ke-2 yang dapat disimpulkan bahwa:

- Waktu pelaksanaan pekerjaan Konstruksi Gudang Garam Nasional Jepara pada minggu ke-2 mengalami keterlambatan.

- Biaya pekerjaan Gudang Garam Nasional pada minggu ke-2 mengalami keuntungan sebesar Rp. 277.461,-- 
Berikut Gambar 18 dan Gambar 19 yang merupakan perhitungan Earned Value Analysis pada pekerjaan Gudang Garam Nasional Pati menggunakan Bahasa Pemrograman C\#.

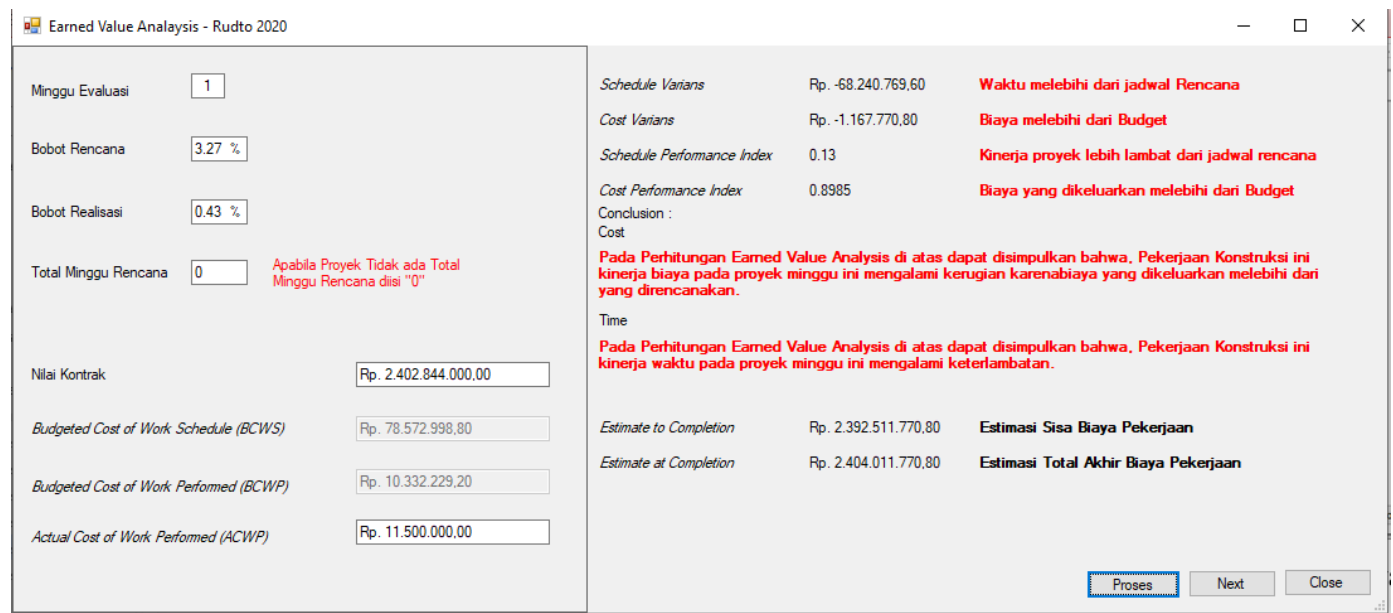

Gambar 18. Perhitungan EVA pekerjaan konstruksi Gudang Garam Nasional Pati minggu ke-1

Berdasarkan Gambar 18, perhitungan EVA yang dilakukan bedasarkan data proyek berupa nilai bobot rencana, nilai bobot realisasi, biaya aktual dan nilai kontrak proyek pada minggu ke-1 yang dapat disimpulkan bahwa:

- Waktu pelaksanaan pekerjaan konstruksi Gudang Garam Nasional Pati pada minggu ke-1 mengalami keterlambatan.

- Biaya pekerjaan Gudang Garam Nasional pada minggu ke-1 mengalami kerugian sebesar Rp. 1.167.770,-.

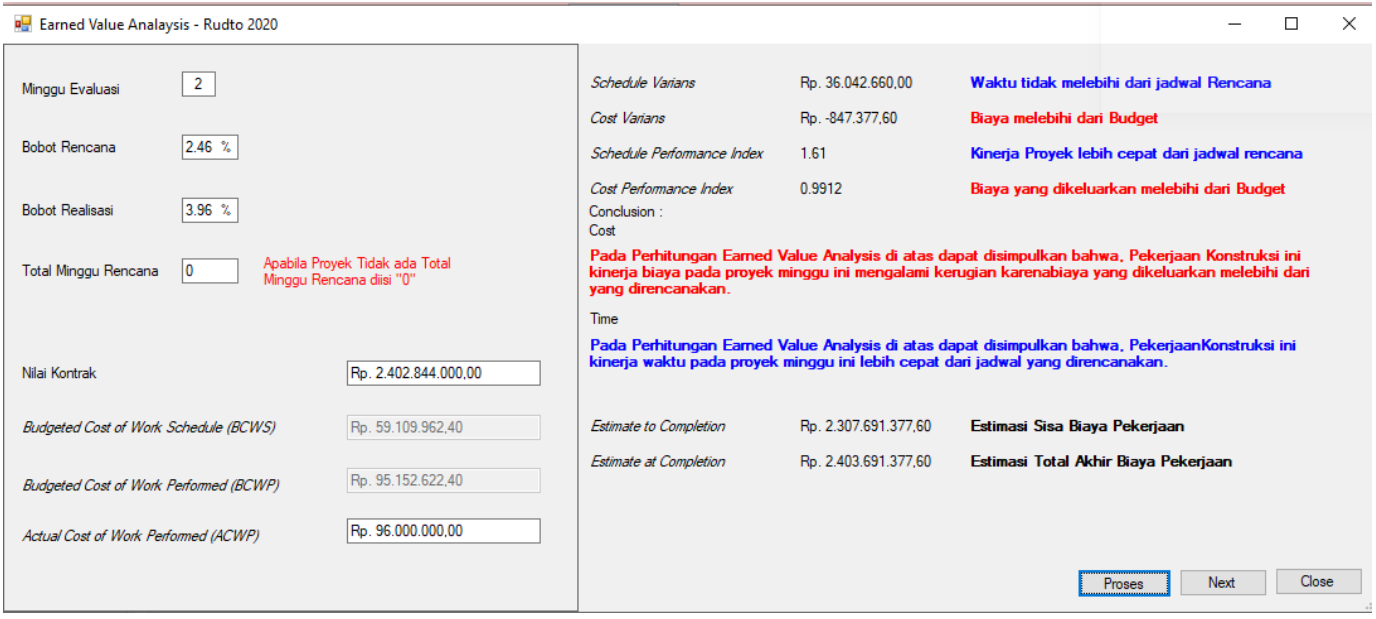

Gambar 19. Perhitungan EVA pekerjaan konstruksi Gudang Garam Nasional Pati minggu ke-2

Berdasarkan Gambar 19, perhitungan EVA yang dilakukan bedasarkan data proyek berupa nilai bobot rencana, nilai bobot realisasi, biaya aktual dan nilai kontrak proyek pada minggu ke-2 yang dapat disimpulkan bahwa:

- Waktu pelaksanaan pekerjaan konstruksi Gudang Garam Nasional Pati pada minggu ke-2 mengalami tepat waktu

- Biaya pekerjaan Gudang Garam Nasional pada minggu ke-2 mengalami kerugian sebesar Rp. 847.377,-. 
Perancangan Otomatis Perhitungan Earned Value pada Rudi Desmanto, et al. Proyek Pembangunan dengan Menggunakan Bahasa Pemrograman C\#

Berikut Gambar 20 dan Gambar 21 yang merupakan perhitungan Earned Value Analysis pada pekerjaan Gudang Garam Nasional Pamekasan menggunakan Bahasa Pemrograman C\#.

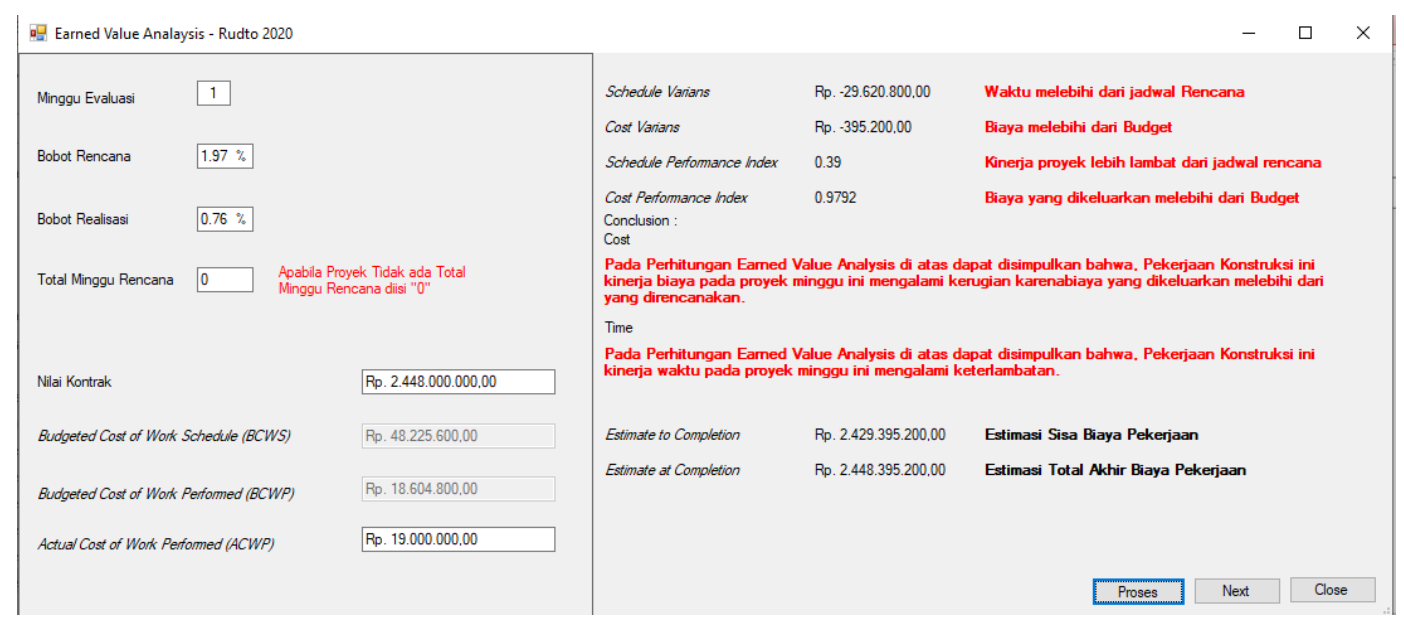

Gambar 20. Perhitungan EVA pekerjaan konstruksi Gudang Garam Nasional Pamekasan minggu ke-1

Berdasarkan Gambar 20, perhitungan EVA yang dilakukan bedasarkan data proyek berupa nilai bobot rencana, nilai bobot realisasi, biaya aktual dan nilai kontrak proyek pada minggu ke-1 yang dapat disimpulkan bahwa:

- Waktu pelaksanaan pekerjaan konstruksi Gudang Garam Nasional Pamekasan pada minggu ke-1 mengalami keterlambatan.

- Biaya pekerjaan Gudang Garam Nasional pada minggu ke-1 mengalami kerugian sebesar Rp. 395.200,-.

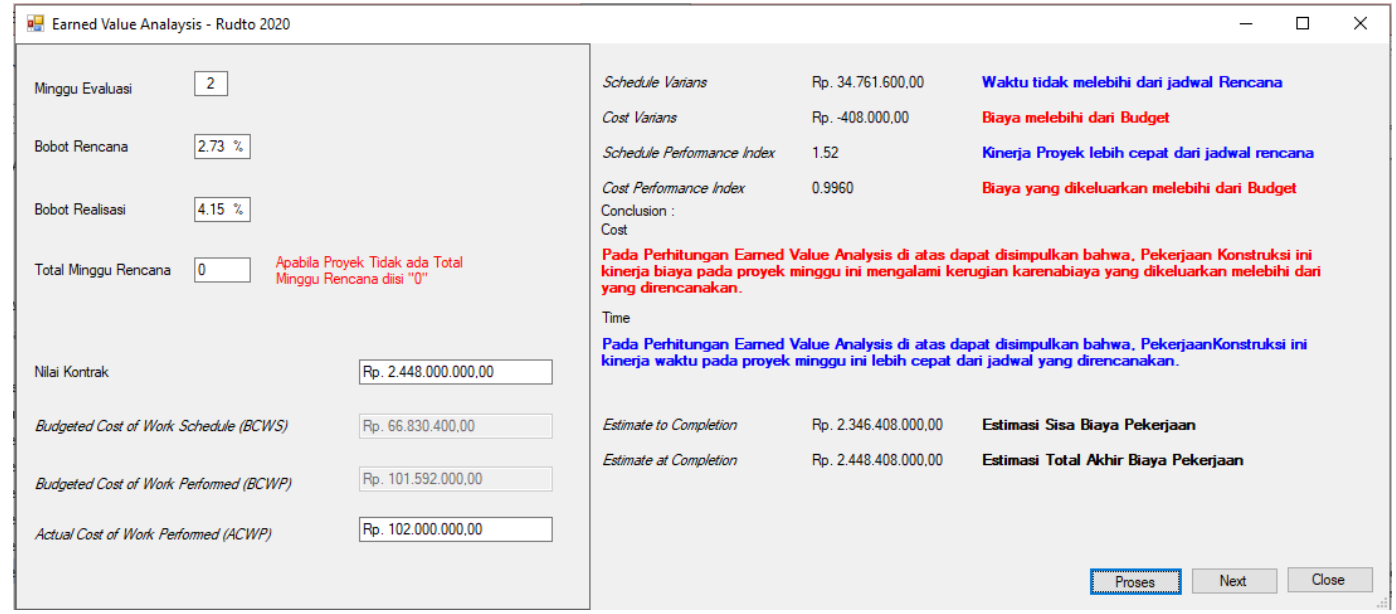

Gambar 21. Perhitungan EVA pekerjaan konstruksi Gudang Garam Nasional Pamekasan minggu ke-2

Berdasarkan Gambar 21, perhitungan EVA yang dilakukan bedasarkan data proyek berupa nilai bobot rencana, nilai bobot realisasi, biaya aktual dan nilai kontrak proyek pada minggu ke-2 yang dapat disimpulkan bahwa:

- Waktu pelaksanaan pekerjaan konstruksi Gudang Garam Nasional Pamekasan pada minggu ke-2 mengalami tepat waktu.

- Biaya pekerjaan Gudang Garam Nasional pada minggu ke-2 mengalami kerugian sebesar Rp. 408.000,-. 


\section{KESIMPULAN DAN SARAN}

\section{Kesimpulan}

Berdasarkan desian program dan analisis peneitian yang diperoleh, dapat disimpulkan hal-hal sebagai berikut:

a) Langkah-langkah untuk mendesain program Earned Value Analysis - Rudto 2020 yaitu sebagai berikut.

- Melakukan studi literlatur mengenai earned value analysis.

- Membuka lembaran baru dengan menggunakan Visual Studio Application dengan bahasa pemrograman C\#.

- Mendesain tampilan lembaran dengan menggunakan toolbox.

- Melakukan pengcodingan untuk perhitungan Earned Value Analysis.

- Melakukan pengcodingan tambahan yang dibutuhkan.

- Melakukan tambahan lembaran.

b) Menganalisis kinerja biaya dan waktu dengan menggunakan Earned Value Analysis pada proyek konstruksi Gudang Garam Nasional pada minggu ke-1 hingga minggu ke-2.

- Gudang Garam Nasional Aceh Utara memiliki kinerja waktu yang baik yang artinya proyek dikerjakan sesuai jadwal yang ditentukan dan kinerja biaya yang buruk yang artinya mengalami kerugian sebesar Rp. $251.380,-$.

- Gudang Garam Nasional Indramayu memiliki kinerja waktu yang buruk yang artinya terjadi keterlambatan para proyek dan kinerja biaya yang buruk yang artinya mengalami kerugian sebesar Rp. 1.168.999,-.

- Gudang Garam Nasional Demak memiliki kinerja waktu yang buruk yang artinya mengalami keterlambatan pada proyek dan kinerja biaya yang buruk yang artinya mengalami kerugian sebesar Rp. 9.916.102,-.

- Gudang Garam Nasional Jepara memiliki kinerja waktu yang buruk yang artinya menglamai keterlambatan dan kinerja biaya yang baik yang artinya mengalami keuntungan sebesar Rp. 277.461,-.

- Gudang Garam Nasional memiliki kinerja waktu yang baik yang artinya proyek dikerjakan sesuai jadwal dan kinerja biaya yang buruk yang artinya mengalami kerugian sebesar Rp. 847.377,-.

- Gudang Garam Nasional Pamekasan memiliki kinerja waktu yang baik yang artinya proyek dikerjakan sesuai jadwal dan kinerja biaya yang buruk yang aritnya mengalami kerugian sebesar Rp. 408.000,-.

\section{Saran}

Berdasarkan analisis dan pembahasan yang telah dilakukan dalam penelitian ini, beberapa hal yang disarankan untuk penelitian ini sebagai berikut:

a) Pelaksanaan pekerjaan konstruksi Gudang Garam Nasional harus memperhatikan dokumen-dokumen perencanaan yang meliputi gambar kerja, jadwal pelaksanaan pekerjaan, metode konstruksi, dan spesifikasi teknis yang telah disusun dan disepakati bersama sehingga tidak terjadi keterlambatan dan kerugian.

b) Untuk peneliti berikutnya dapat mengembangkan kemampuan program C\# khususnya terkait output pelaporan.

\section{DAFTAR PUSTAKA}

Ervianto, W. I., 2005. Manajemen Proyek Konstruksi. Edisi 2. Yogyakarta : CVAndi Offset.

Miftha, M. Faridhol, dkk. 2018. Analisa Kinerja Biaya Dan Waktu Dengan Metode Earned Value Pada Proyek Gedung Balai Nikah Dan Manasik Haji Kecamatan Sijunjung, Kabupaten Sijunjung. Sumatera Barat. Universitas Brawijaya.

N., Rifqi Auzan, dkk. 2017. "Pengendalian Biaya Dan Waktu Proyek Dengan Metode Konsep Nilai Hasil (Earned Value)". Jurnal Karya Teknik Sipil. 6(4), 460-470.

Santoso, Pramudita Budi. 2020. Earned Value Analysis Pada Pekerjaan Konstruksi Gudang Garam Nasional. Fakultas Teknik Sipil. Universitas Tarumanegara, Jakarta.

Soeharto, Iman, 1999. Manajemen Proyek Dari Konseptual Sampai Operasional Jilid I. Kanisius, Jakarta.

Soemardi, B. W., dkk. (2007). Konsep Earned Value Untuk Pengelolaan Proyek Konstruksi, Fakultas Teknik Sipil dan Lingkungan, Institut Teknologi Bandung, Bandung. 
Perancangan Otomatis Perhitungan Earned Value pada

Rudi Desmanto, et al.

Proyek Pembangunan dengan Menggunakan Bahasa

Pemrograman C\# 